\title{
Normal insulin receptor tyrosine kinase activity and glucose transporter (GLUT 4) levels in the skeletal muscle of hyperinsulinaemic hypertensive rats
}

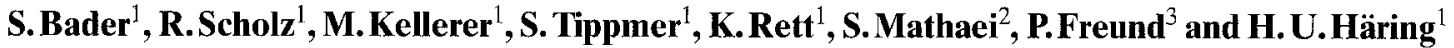 \\ ${ }^{1}$ Institut für Diabetesforschung, München, ${ }^{2}$ Universitätsklinik Eppendorf, Hamburg, and ${ }^{3}$ Boehringer Mannheim, Mannheim, FRG
}

\begin{abstract}
Summary. The spontaneous hypertensive rat is an animal model characterized by a syndrome of hypertension, insulin resistance and hyperinsulinaemia. To elucidate whether in analogy to other insulin resistant animal models an inactivity of the insulin receptor kinase or an alteration of the glucose transporter (GLUT 4) level in the skeletal muscle might contribute to the pathogenesis of insulin resistance we determined insulin receptor kinase activity and GLUT 4 level in the hindlimbs of spontaneous hypertensive rats and normotensive control rats. Normotensive normoinsulinaemic Lewis and Wistar rats were used as insulin sensitive controls, obese Zucker rats were used as an insulin resistant control with known reduced skeletal muscle insulin receptor kinase activity. Binding of ${ }^{125} \mathrm{I}$-insulin, crosslinking of ${ }^{125} \mathrm{I}-\mathrm{B}^{26}$-insulin, autophosphorylation in vitro with ${ }^{32} \mathrm{P}$-ATP and phosphorylation of the synthetic substrate Poly (Glu 4: Tyr 1) were performed after partial purification of solubilized receptors on
\end{abstract}

wheat germ agglutinin columns. GLUT 4 levels were determined by Western blotting of subcellular muscle membranes. Insulin receptors from spontaneous hypertensive rats compared to those from Lewis and Wistar rats showed no difference of the binding characteristics or the in vitro auto- and substrate phosphorylation activity of the receptor, while in the Zucker rats the earlier described insulin receptor kinase defect was clearly evident. Western blots of subcellular muscle membrane fractions with antibodies against GLUT 4 revealed no difference in transporter levels. These data suggest that insulin resistance in spontaneous hypertensive rats is caused neither by an insulin receptor inactivity nor by a decreased number of glucose transporters in the skeletal muscle.

Key words: Spontaneous hypertensive rat, insulin receptor kinase, glucose transporter.
There is increasing evidence that hypertension is associated with insulin resistance and compensatory hyperinsulinaemia [1-8]. The molecular mechanism causing insulin resistance in states of hypertension is not understood. Insulin resistance might be caused by abnormalities of insulin signal transduction at any level of the signal transmitting chain in the target cells of the hormone $[9$, 10], i. e. at the level of insulin binding, activation of the insulin receptor kinase, post-kinase signal transmitting events or directly at the level of major effector systems such as the glucose transport system or the glycogen synthase. In insulin resistant animal models, which show characteristics of human Type 2 (non-insulin-dependent) or Type 1 (insulin-dependent) diabetes mellitus, such as the Zucker rat [10-12], gold-thio-glucose-mice [13], ob/ob mice [14] or streptozotocin-treated rats [15] an impairment of insulin signal transduction at the level of the insulin receptor kinase in the skeletal muscle has been described. Furthermore, in streptozotocin-induced diabetes defects at the level of the glucose transporter in fat and skeletal muscle were observed [16, 17]. In human Type 2 diabetes insulin resistance is associated with an inactivity of the insulin receptor kinase of the skeletal muscle $[10$, $18,19]$, the liver and the fat $[20,21]$. Furthermore, in fat an abnormality of the glucose transporter system was observed [22], while in the skeletal muscle controversial results were obtained [23-25]. In analogy to these observations it might be speculated that insulin resistance in hypertension could be caused or at least aggravated by an impairment of signal transduction at the level of the insulin receptor kinase or the glucose transporter. An animal model which shows an association of hypertension, insulin resistance and hyperinsulinaemia is the spontaneous hypertensive rat [26]. Recently Reaven et al. [27] have shown that adipocytes from spontaneous hypertensive rats (SHR) display an insulin resistance of the glucose uptake mechanism. In other animal models of insulin resistance [10-17] as well as in human pre-diabetes $[28,29]$ and Type 2 diabetes [30] it was shown that the predominant role for the pathogenesis of insulin resistance is played by 
the skeletal muscle. Therefore the aim of our study was to determine whether the skeletal muscle of the SHR shows an abnormality of insulin signal transduction at the level of the insulin receptor kinase or at the level of the glucose transporter. Insulin receptor kinase activity of the skeletal muscle from SHR as well as GLUT 4 levels were compared with two types of rats with normal insulin sensitivity, normal insulin levels and normal blood pressure i. e. Lewis rats and Wistar rats. The kinase data were also compared with the insulin receptor kinase activity of an animal model with insulin resistance and hyperinsulinaemia, where an inactivity of the insulin receptor kinase has been demonstrated [10], i.e. the Zucker rat.

\section{Materials and methods}

\section{Materials}

Porcine insulin was purchased from Novo Nordisk (Bagsværd, Denmark), [ $\left.{ }^{32} \mathrm{P}\right] \mathrm{ATP}, 2900 \mathrm{Ci} / \mathrm{mmol}$, from Du Pont de Nemours (Dreieich, FRG), Triton X-100 from Sigma (Munich, FRG). Aprotinin, benzamidine, vanadate, bacitracin, natriumfluoride, natriumorthophosphate, phenylmethylsulphonyl fluoride (PMSF) and $\mathrm{N}$-acetylglucosamide were obtained from Sigma. Wheat germ agglutinin coupled to aga rose was from Miles/ICN (Eschwege, FRG). All reagents for SDS-PAGE were from Bio-Rad (Munich, FRG), and ail other reagents were of the best grade commercially available. Insulin (human) was purchased from Hoechst (Frankfurt, FRG). For homogenisation we used an Ultra-Turrax from Janke and Kunkel (Staufen im Breisgau, FRG). For autoradiography X-Omat AR5 diagnostic film was used from Kodak (Rochester, NY, USA). The SHR, Wistar-Kyoto rats and Lewis rats (320-340 g body weight) came from Bochringer (Mannheim, FRG). The polyclonal serum directed against the C-terminal end of GLUT 4 was the kind gift of Dr. T.Plough (Copenhagen, Denmark). The polyclonal serum against GLUT 1 was obtained from Wak-Chemie (Homburg, FRG), nitrocellulose was from Schleicher and Schuell (Dassel, FRG), the chemiluminescence detection system was from Amersham (Braunschweig, FRG)

\section{Insulin receptor kinase}

Receptor preparation: muscle receptor was prepared from skeletal muscle as previously described [31]. Skeletal muscle tissue was homogenized in the presence of protease inhibitors $(2.5 \mathrm{mmol} / \mathrm{l}$, PMSF); 1000 trypsin inhibiting units/ml, aprotinin; $10 \mathrm{mmol} / \mathrm{l}$ benzamidin, $0.01 \%$ bacitracin ( $\mathrm{g} /$ volume) in a buffer containing $25 \mathrm{mmol} / 1$ Hepes ( $\mathrm{pH} 7$.4). The homogenates were centrifuged at $11,000 \times \mathrm{g}$ for $20 \mathrm{~min}$, the pellet was then solubilized with Triton X-100 at a final concentration of $1 \%$ (by volume). Insoluble material was removed by centrifugation at $50,000 \times g$ for $50 \mathrm{~min}$ and the supernatant was applied to columns containing wheat germ agglutinin coupled to agarose. After extensive washing with $25 \mathrm{mmol} / \mathrm{l}$ Hepes buffer (pH 7.4) containing $0.05 \%$ Triton $\mathrm{X}-100,10 \%$ glycerin, $120 \mathrm{mmol} / \mathrm{l}$ $\mathrm{NaCl}, 2.5 \mathrm{mmol} / \mathrm{l} \mathrm{KCl}, 1 \mathrm{mmol} / \mathrm{l} \mathrm{MgCl}, 1 \mathrm{mmol} / 1 \mathrm{CaCl}_{2}$ the bound material was eluted with the same buffer supplemented with $0.3 \mathrm{~mol} / \mathrm{l} \mathrm{N}$-acetylglucosamine.

Binding to solubilized receptor: solubilized and wheat germ purified receptor was prepared as described above. Aliquots of the wheat germ eluate containing $5 \mu \mathrm{g}$ of protein were incubated with $\left[{ }^{125} \mathrm{I}-\right.$ Tyr $\left.{ }^{\mathrm{A} 14}\right]$-insulin $\left(3 \times 10^{-11} \mathrm{~mol} / 1,3000 \mathrm{cpm} / \mathrm{fmol}\right)$ and various concentrations of unlabelled insulin for $45 \mathrm{~min}$ at $22^{\circ} \mathrm{C}$ in a medium of $25 \mathrm{mmol} / 1$ Tris ( $\mathrm{pH} 7.4$ ), $5 \mathrm{mmol} / \mathrm{l} \mathrm{MgSO}_{4}$ and $0.5 \mathrm{~g} \%$ bovine serum albumin (BSA). Separation of the free and receptor-bound insulin was then performed using dextrane-coated charcoal. Scatchard analysis was performed using a computer program written by G. A. McPherson [32].

\section{Affinity crosslinking of ${ }^{125} I B^{25}$ insulin to solubilized receptor}

Crosslinking experiments were performed as described [33]. A $50 \mu 1$ sample (0.5-2 $\mu \mathrm{g}$ of protein) of wheat germ agglutinin purified receptor eluate was incubated with $0.08 \mathrm{nmol} / 1^{125}$ iodotyrosyl- $\mathrm{B}^{26}$-insulin for $12 \mathrm{~h}$ at $4^{\circ} \mathrm{C}$. Tubes were chilled on ice and disuccinimidyl substrate (final concentration $25 \mu \mathrm{mol} / 1$ ) was added for $20 \mathrm{~min}$ at $4^{\circ} \mathrm{C}$. The incubation was terminated by addition of Laemmli buffer containing $100 \mathrm{mmol} / 1$ dithiothreitol and Tris/ $\mathrm{HCl}(20 \mathrm{mmol} / \mathrm{l}, \mathrm{pH} 7.4)$ and subsequent boiling for $25 \mathrm{~min}$ at $95^{\circ} \mathrm{C}$. The reaction products were analysed by SDS-PAGE (7.5\% gel) and autoradiography [34].

\section{Autophosphorylation of the insulin receptor}

For the standard phosphorylation assay approximately $4 \mu \mathrm{g}$ of wheat germ purified proteins were pre-incubated at $22^{\circ} \mathrm{C}$ for 30 min with insulin $\left(10^{-10}-10^{-6} \mathrm{~mol} / \mathrm{l}\right)$ or without insulin. This was followed by an incubation with $\left[{ }^{32} \mathrm{P}\right]-\mathrm{ATP}(10 \mathrm{Ci} / 75 \mu \mathrm{l}$ volume), in $25 \mathrm{mmol} / 1$ Hepes buffer (pH 7.4), containing $0.1 \%$ (by volume) Triton X-100, $10 \mathrm{mmol} / \mathrm{l} \mathrm{MnCl} 2,12 \mathrm{mmol} / 1 \mathrm{NaCl}, 0.5 \mathrm{mmol} / \mathrm{l} \mathrm{KCl}, 0.25 \mathrm{mmol} / \mathrm{l}$ $\mathrm{CaCl}_{2}, 0.1 \mathrm{mmol} / \mathrm{MgSO} \mathrm{Mg}_{4}, 0.25 \mathrm{~g} \% \mathrm{BSA}$, and $1 \mathrm{mmol} / \mathrm{l}$ vanadate at $22^{\circ} \mathrm{C}$. The incubation was stopped by addition of Laemmli buffer and boiling for $30 \mathrm{~min}$. Subsequently phosphoproteins were separated by PAGE [34]. The phosphoproteins identified by the autoradiography were cut from the gel and counted in a scintillation counter.

\section{Substrate phosphorylation}

Substrate phosphorylation activity was analysed by a modification of the method of Braun et al. [35]. Approximately 0.5-1.0 $\mu \mathrm{g}$ of wheat germ purified proteins were pre-incubated with insulin $\left(10^{-6}\right.$ $10^{-10} \mathrm{~mol} / \mathrm{l}$ ) and without insulin for $30 \mathrm{~min}$ at $22^{\circ} \mathrm{C}$. This was followed by an incubation with $\left[{ }^{32} \mathrm{P}\right] \mathrm{ATP}(50 \mu \mathrm{mol} / 1,0.005 \mathrm{mCi})$ in the final volume of $50 \mu \mathrm{l}$ containing $25 \mathrm{mmol} / \mathrm{l}$ Hepes buffer, containing $0.05 \%$ (by volume) Triton X-100, $12 \mathrm{mmol} / 1 \mathrm{MgCl}_{2}, 12 \mathrm{mmol} / \mathrm{l} \mathrm{MnCl}_{2}$, $1 \mathrm{mmol} / \mathrm{l}$ vanadate, and $1 \mathrm{mmol} / /$ Poly (Glu 4 : Tyr 1 ) for $1 \mathrm{~h} \mathrm{at} 22^{\circ} \mathrm{C}$. The phosphorylation was stopped by application of the reaction mixture to Whatman $3 \mathrm{MM}$ paper squares washed with $20 \mathrm{mmol} / \mathrm{l}$ sodium pyrophosphate. The papers were washed six times in $10 \%$ (by volume) trichloric acid containing $20 \mathrm{mmol} / \mathrm{l}$ sodium pyrophosphate and counted with a scintillation mixture in a beta-counter.

\section{Glucose transporter}

Treatment of animals and hindlimb preparation: SHR (12-13 weeks old) and control Wistar rats of the same age all with body weights ranging from $320-340 \mathrm{~g}$ respectively were injected with insulin ( 3 mU/l Altinsulin, Hoechst). Subsequently the glucose concentration was checked every 4 min with Glucostix (Bayer, Leverkusen, FRG). The rats were killed $15 \mathrm{~min}$ after the injection. The muscles of both hindlimbs were quickly removed, dissected on ice, and deep frozen at $-80^{\circ} \mathrm{C}$ within 3 min of the killing.

\section{Membrane preparation}

For the preparation of membrane fractions enriched in plasma membranes or low density membranes (LDM) we used a method as it is also described in the flow sheet (Fig. 1). The essential steps of the purification procedure to obtain fractions enriched with plasma membrane or LDM were as follows: muscles were homogenized with an Ultra Turrax (Braun, Melsungen, FRG) four times full speed for $10 \mathrm{~s}$. Approximately $4 \mathrm{~g}$ tissue was used in each group for the preparation. The homogenate was dissolved in cold $\left(4^{\circ} \mathrm{C}\right)$ buffer $(0.2 \mathrm{~mol} / \mathrm{l}$ Tris $\times \mathrm{HCl}, 10 \mathrm{mmol} / 1$ EDTA, $255 \mathrm{mmol} / \mathrm{l}$ sucrose, pH 7.4). Containing the following protease and phosphatase inhibitors $(0.2 \mathrm{mg} / \mathrm{ml}$ bacitracin, 1000 trypsin inhibiting units $/ \mathrm{ml}$ aprotinin, $1 \mathrm{mmol} / \mathrm{l} \mathrm{PMSF}, 0.2 \mathrm{mg} / \mathrm{ml}$ benzamidine, $100 \mathrm{mmol} / \mathrm{l}$ sodium flu- 


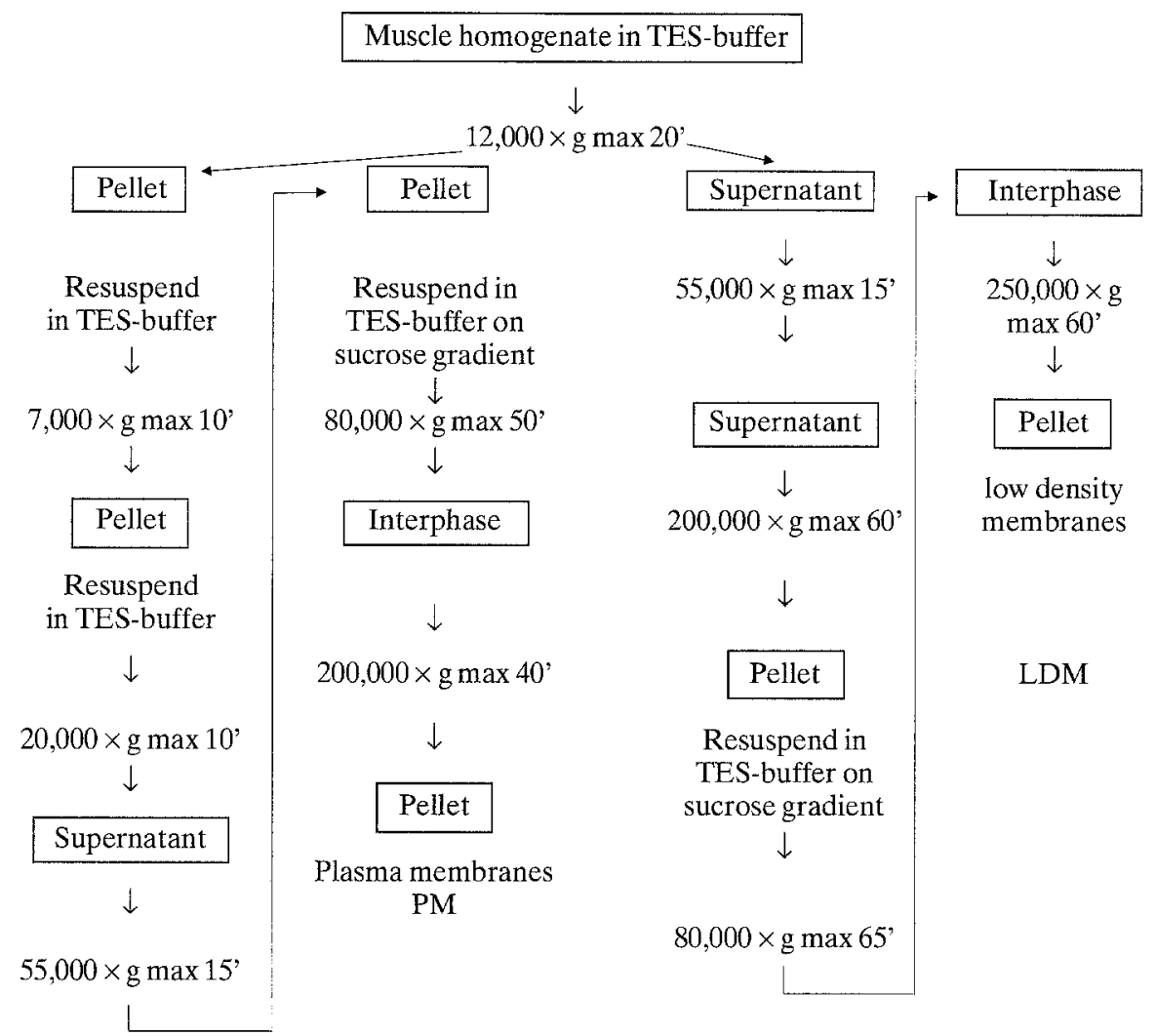

Fig. 1. Schematic presentation of isolation procedure for plasma membranes (PM) and low density membranes (LDM) from the rat hindlimb muscle. TES $(2 \mathrm{mmol} / \mathrm{l}$ Tris, $100 \mathrm{mmol} / \mathrm{l} \mathrm{EDTA,} 225 \mathrm{mmol} / \mathrm{l}$ sucrose) oride, $10 \mathrm{mmol} / \mathrm{l}$ sodium pyrophosphate, $1 \mathrm{mmol} / \mathrm{l}$ orthovanadate) and pottered in a glass/teflon potter for ten times. After homogenization the tissue was centrifuged at $12,000 \mathrm{~g}$ for $20 \mathrm{~min}$. The supernatant consisting of fractions enriched with high density membranes (HDM) and LDM was centrifuged for $15 \mathrm{~min}$ at 55,000 $\mathrm{g}$ to separate the LDM-enriched membranes from the HDM-enriched membranes. To obtain the crude membrane pellet the supernatant was again centrifuged in a high-speed centrifuge for $60 \mathrm{~min}$ at $200,000 \mathrm{~g}$. The pellet was resuspended in buffer, pottered again and centrifuged at $7,000 \mathrm{~g}$ for $10 \mathrm{~min}$. The resulting plasma membrane-enriched supernatant was centrifuged again for $15 \mathrm{~min}$ at $55,000 \mathrm{~g}$ to obtain the crude membrane pellet. Both pellets were resuspended in buffer, pottered again and then layered on a $38.3 \%$ sucrose gradient. The plasma membrane-enriched fraction was centrifuged in an ultracentrifuge at $80,000 \mathrm{~g}$ for $50 \mathrm{~min}$. The LDM-enriched fraction was centrifuged for $65 \mathrm{~min}$ at $80,000 \mathrm{~g}$. Both membrane-pellets were collected then at the respective sucrose interphase, diluted four-fold with buffer and dispersed by mechanical disruption through a syringe needle. Finally the plasma membrane-enriched fraction was centrifuged for $40 \mathrm{~min}$ at $200,000 \mathrm{~g}$. The LDM-enriched fraction was centrifuged for $60 \mathrm{~min}$ at $250,000 \mathrm{~g}$. To determine the purity of the membrane fractions marker enzymes were measured in the cellular homogenate and the membrane fractions. Ouabain sensitive $\mathrm{Na}^{+} \mathrm{K}^{+}$-ATPase served as a marker for plasma membrane [36], uridine diphosphate (UDP) galactosyl-transferase as marker for LDM [37]. Protein concentration was determined by Bio-Rad assay.

Table 1. Animal characteristics

\begin{tabular}{|c|c|c|}
\hline & SHR rats & $\begin{array}{l}\text { Wistar-Kyoto } \\
\text { and Lewis rats }\end{array}$ \\
\hline Blood pressure $[\mathrm{mm} \mathrm{Hg}]$ & $215 \pm 5$ & $154 \pm 8$ \\
\hline $\begin{array}{l}\text { Fasting insulin levels } \\
{[\mu \mathrm{U} / \mathrm{ml}]}\end{array}$ & $29.6 \pm 8$ & $19.5 \pm 4$ \\
\hline Body weight [g] & $335 \pm 3$ & $319 \pm 2$ \\
\hline
\end{tabular}

SHR, spontaneous hypertensive rat

\section{Western blotting}

Membranes $(15 \mu \mathrm{g}$ protein) were subjected to $10 \%$ SDS-PAGE [34] in the presence of $10 \mathrm{mmol} / \mathrm{l}$ dithiothreitol. Proteins were transferred to nitrocellulose by electroblotting (buffer: $192 \mathrm{mmol} / \mathrm{l}$ glycine, $25 \mathrm{mmol} / \mathrm{l}$ Tris, $10 \%$ methanol, $\mathrm{pH}=7.4,2 \mathrm{~h} 250 \mathrm{~mA}$ ). Following transfer the filters were blocked with $5 \%$ non-fat dry milk in Tris buffered saline for $1 \mathrm{~h}$ at room temperature and subsequently incubated with the first antibody (GLUT 4 and GLUT 1 dilution in Tris buffered saline with $1 \%$ dry milk) overnight at $4{ }^{\circ} \mathrm{C}$. After incubation with the specific antibody, nitrocellulose was washed several times in Tris buffered saline with $20 \mathrm{mmol} / \mathrm{I}$ Tris, $2.5 \%$ non-fat dry milk, $1 \%$ Triton X-100.

Horseradish peroxidase labelled $\operatorname{IgG}$ was then bound to the immunocomplexes. Visualization of the immunolabelled bands was carried out by autoradiography after addition of a chemiluminescence reagent.

\section{Scanning densitometry}

After autoradiography the density of the labelled $45 \mathrm{kDa}$ bands was measured using a type Elscript 400 scanner from Hirschmann GmbH (Munich, FRG). Measurements were performed with a $0.2 \mathrm{~mm}$ window in an extinction range of 2 or 4 by $100 \mu \mathrm{m}$ steps.

\section{Statistical analysis}

The data are expressed as mean values and SD.

\section{Results}

\section{Insulin receptor}

Table 1 shows the characteristics of SHR, Lewis and Wistar rats. As described earlier blood pressure values of $215 \pm 5 \mathrm{~mm} \mathrm{Hg}$ were found in SHR, while Lewis and Wistar 

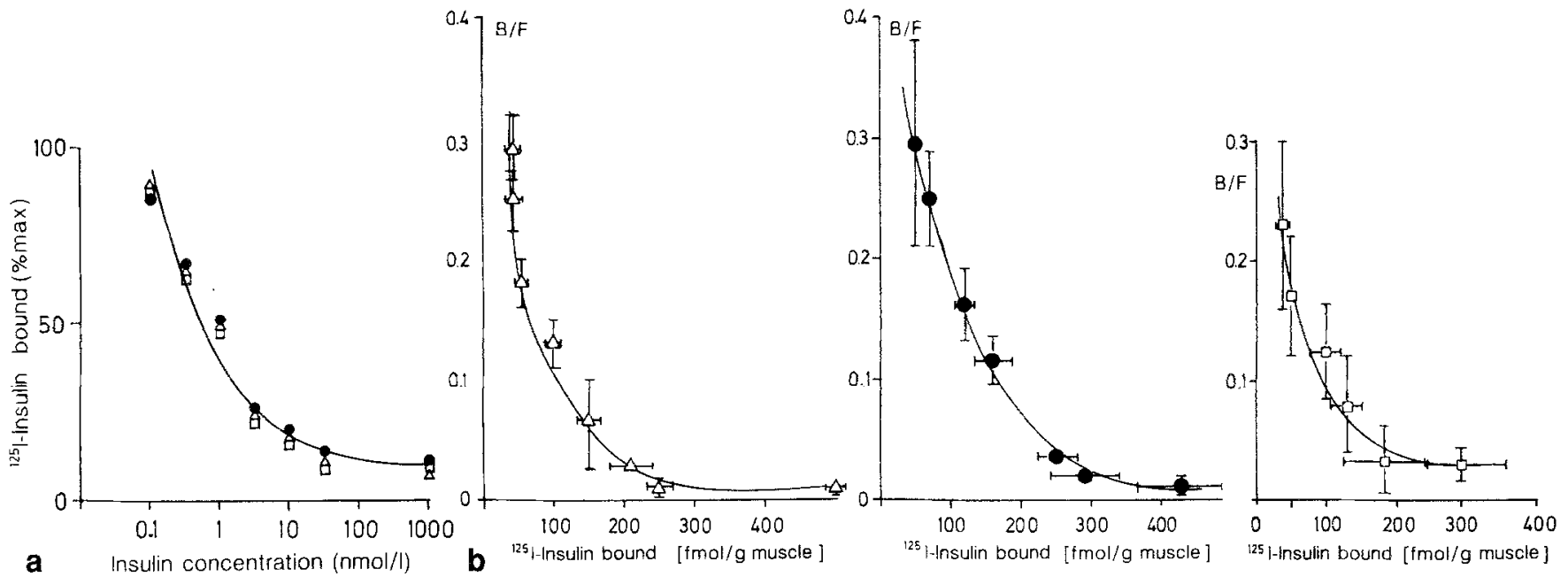

Fig. 2. a Displacement curves of ${ }^{125} \mathrm{I}$-insulin to partially purified insulin receptors from skeletal muscle of spontaneous hypertensive rats $(\Delta)$ and Lewis $(\bullet)$ and Wistar $(\square)$ rats. ${ }^{125}$ I-insulin-binding was performed as described in the Materials and methods section. Mean values of five preparations are shown. b Scatchard plots of ${ }^{125} \mathrm{I}$-insulin binding to partially purified insulin receptors from skeletal

rats had clearly lower levels. Furthermore insulin levels were increased in SHR compared to the normotensive control animals indicating the earlier described insulin resistance of these animals [26, 27]. Receptors were isolated from skeletal muscle of all three groups in parallel experiments. Figure $2 \mathrm{a}$ shows the binding values of equal amounts of protein from the wheat germ agglutinin purification step. Insulin displacement curves are shown in Figure 2 a. It is evident that identical binding values were found for SHR, Lewis and Wistar rats. In Figure $2 b$ the same data are presented as Scatchard plots. No alteration of receptor affinity or receptor number can be detected. For chemical crosslinking of receptors equal amounts of protein were used. Figure 3 shows the labelling of $\alpha$-subunits from insulin receptors from all three groups. Scanning densitometry of the labelling of the bands revealed equal amounts of ${ }^{125} \mathrm{IB}^{26}$ insulin crosslinking to receptors from all

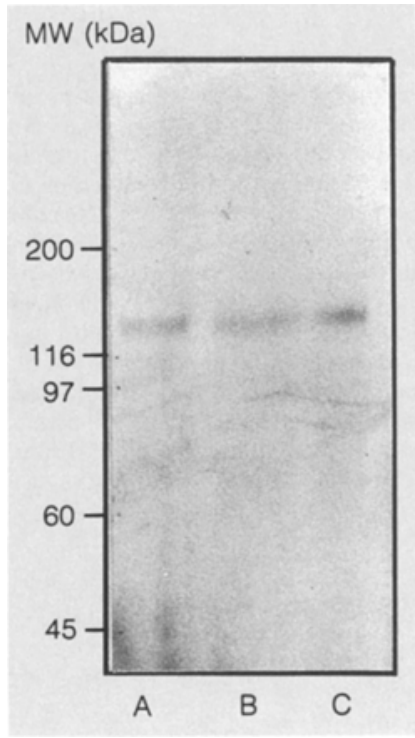

Fig. 3. Autoradiogram showing crosslinking of ${ }^{125} \mathrm{I}^{-\mathrm{B}^{26}}$-insulin to partially purified insulin receptors from skeletal muscle of spontaneous hypertensive rats (SHR), Lewis and Wistar rats. Crosslinking for equal amounts of the eluate from the wheat germ agglutinin columns was performed as described in the Materials and methods section. A, SHR; B, Wistar-Kyoto rats; C, Lewis rats muscle of spontaneous hypertensive rats $(\Delta)$, Lewis $(\bullet)$ and Wistar ( $\square$ ) rats. Mean values of five preparations \pm SEM are shown. $B / F$, bound/free; Mean \pm SEMs of high affinity binding sites for the three groups: $n=5 ;$ SHR: $1.08 \times 10^{-10} \pm 0.32 \times 10^{-10}$ : Wistar: $1.08 \times$ $10^{-10} \pm 0.42 \times 10^{-10}$, Lewis: $1.30 \times 10^{-10} \pm 0.47 \times 10^{-10}$

three groups as already expected on the basis of the binding data. We now used equal amounts of receptors to compare the insulin effect on ${ }^{32} \mathrm{P}$ incorporation into the $\beta$-subunit. Figure 4 a shows autoradiograms of the ${ }^{32} \mathrm{P}$ incorporation into the $\beta$-subunit of partially purified insulin receptors from SHR, Wistar and Lewis rats. To determine ${ }^{32} \mathrm{P}$ incorporation into the $\beta$-subunits the bands were cut out from the gel and the radioactivity was measured in a betacounter. The mean values \pm SEM of five preparations from each group performed in parallel did not reveal any difference in maximal ${ }^{32} \mathrm{P}$ incorporation and submaximal values. When the data were plotted as shown in Figure $4 \mathrm{~b}$ as percentage of the maximal insulin effect, it is evident that there is no difference in the dose-response curve of the activation of $\beta$-subunit autophosphorylation between the three groups. For comparison isolated receptors were also partially purified in parallel from the skeletal muscle of lean, insulin sensitive and obese hyperinsulinaemic insulin resistant Zucker rats. The data which are used as a further control are shown in Figure 5. As described earlier [11] there is a decrease of the ${ }^{32} \mathrm{P}$ incorporation into the $\beta$-subunit of the receptor isolated from the skeletal muscle of the insulin resistant Zucker rat. Figure 6a shows the effect of insulin on substrate phosphorylation. Similarly as seen for autophosphorylation no difference can be detected between SHR, Lewis or Wistar rats. Figure 6 b shows for comparison the effect of insulin on substrate phosphorylation by receptors isolated from lean or obese Zucker rats. Clearly a reduction of the kinase activity from the skeletal muscle of the Zucker rats can be seen.

\section{Glucose transporter}

To assess the glucose transporter level skeletal muscle was fractionated as described in the Materials and methods section. To determine the purity of the plasma membraneenriched fraction and the LDM enriched fraction, $\mathrm{Na} / \mathrm{K}$ ATPase and UDP-galactosyl-transferase were deter- 


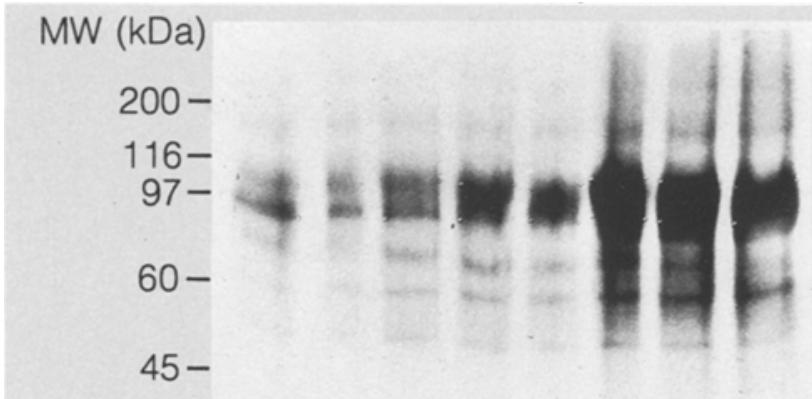

a
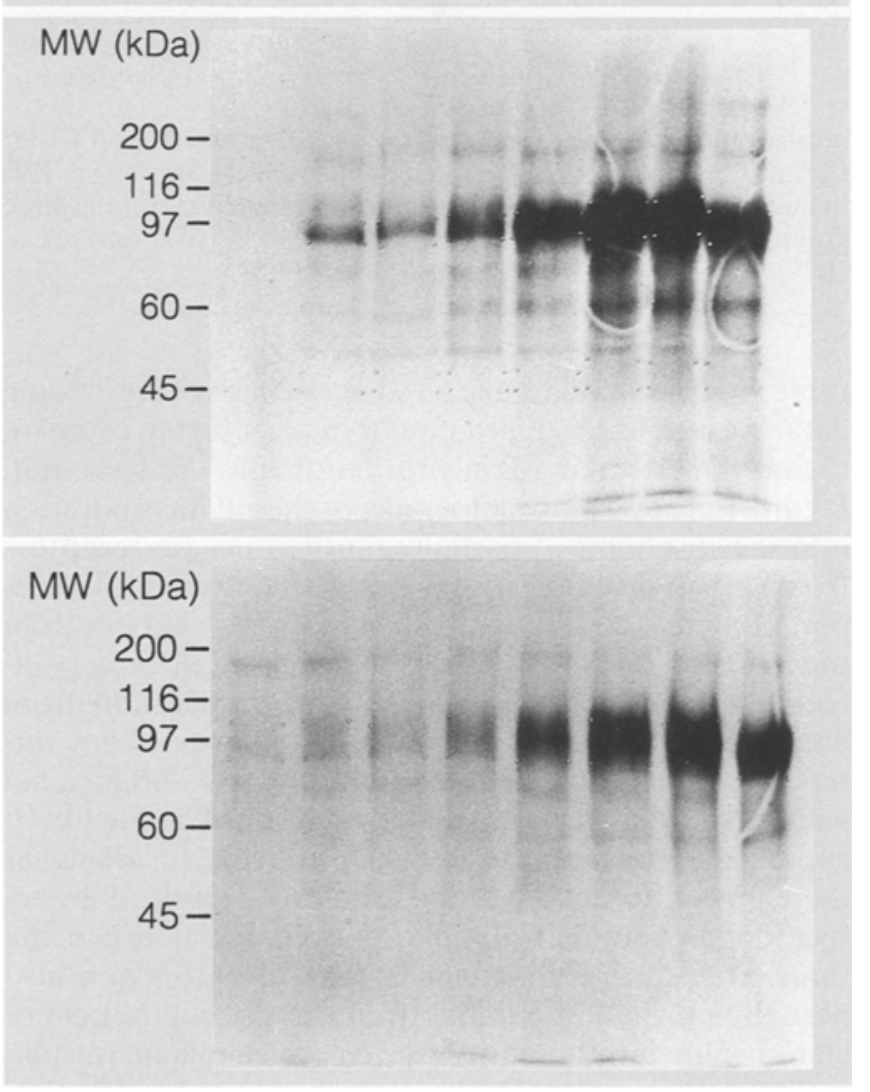

b

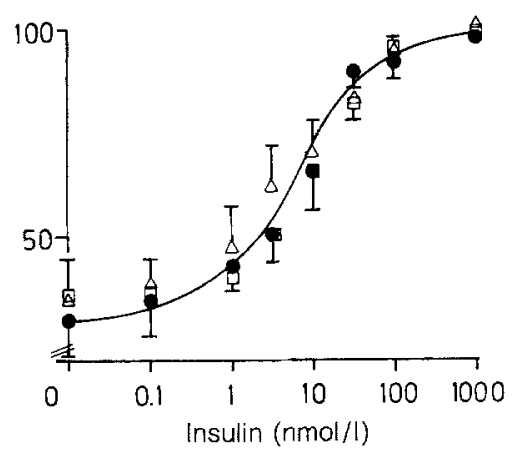

Fig. 4a,b. Autoradiogram of $\left.{ }^{32} \mathrm{P}\right]$-incorporation into the $\beta$-subunit of partially purified insulin receptor from the skeletal muscle of spontaneous hypertensive rats (SHR), Wistar (WK) and Lewis rats. Insulin receptor was phosphorylated with $\left[{ }^{32} \mathrm{P}\right]$ - ATP after in vitro insulin stimulation as described under experimental procedures and then applied to SDS-PAGE gels. a Three representative autoradiograms showing the dose-response of insulin-stimulated $\left[{ }^{32} \mathrm{P}\right]$-incorporation into the $95 \mathrm{kDa} \beta$-subunit of the insulin receptor from SHR (top panel), WK (centre panel) and Lewis (lower panel) muscle. b The average dose-response curves of the SHR $(\triangle)$ and WK $(\square)$ and Lewis $(\bullet)$ are plotted as \% of maximal $\left[{ }^{32} \mathrm{P}\right]$ phosphate incorporation (mean \pm SEM)

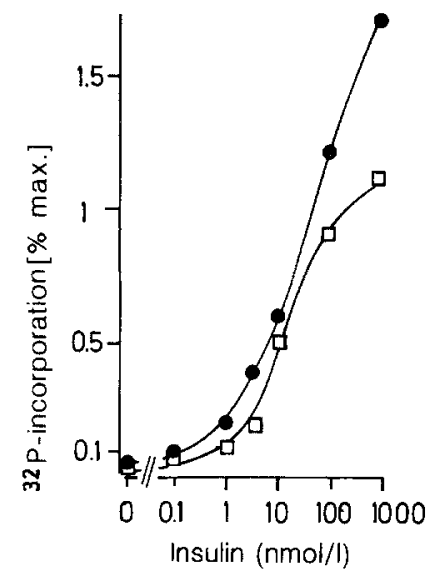

Fig. 5. Autophosphorylation of the insulin receptor from the skeletal muscle of the insulin resistant Zucker rat. $\left[{ }^{32} \mathrm{P}\right]$-incorporation into the $\beta$-subunit of partially purified insulin receptors from skeletal muscle of lean ( ) and obese $(\square)$ Zucker rats was performed as described in the Materials and methods section. Labelled bands were cut from the gel and counted. Mean values of three experiments are shown.
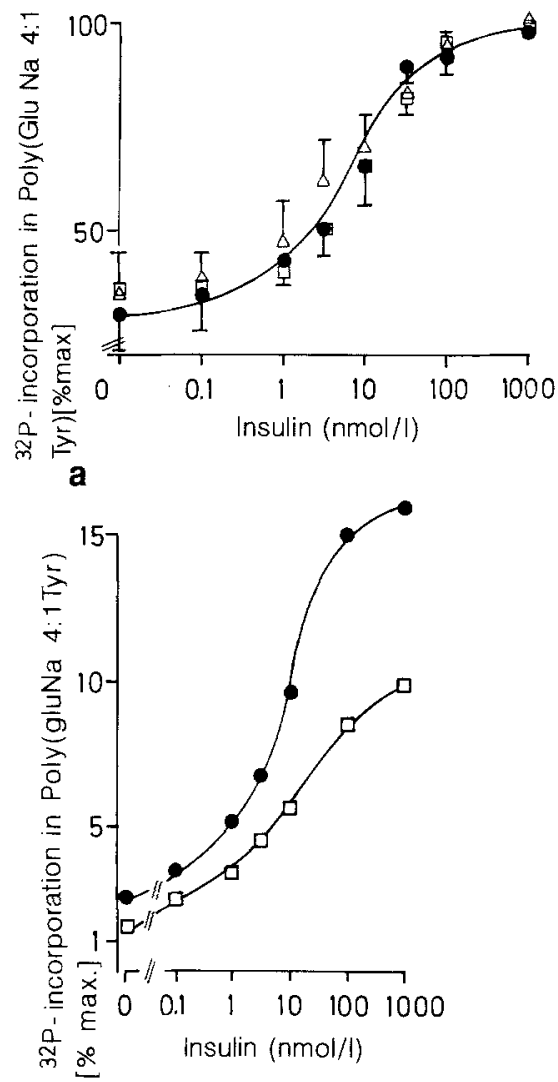

Fig. 6. a Insulin dose-response curve of Poly (Glu 4: Tyr 1) phosphorylation for spontaneous hypertensive rats $(\triangle)$ and control Wistar $(\square)$ and Lewis $(\bullet)$ rats. The substrate phosphorylation assay was carried out with each muscle sample as described under experimental procedures for $1 \mathrm{~h}$ using $1 \mathrm{mmol} / \mathrm{l}$ Poly(Glu 4: Tyr 1). The kinase activity was measured in the absence of insulin and at $0.1-1000 \mathrm{nmol} / \mathrm{h}$ insulin using equal amounts of partially purified insulin receptor as determine by insulin binding. Mean values \pm SEM of five experiments are shown. b Insulin dose-response curve of Poly(Glu 4: Tyr 1) phosphorylation for lean $(\bullet)$ and obese ( $\square$ ) Zucker rats. The substrate phosphorylation assay was carried out with each muscle sample as described under experimentalprocedures for $1 \mathrm{~h}$ using 1 mmol/1 Poly (Glu 4: Tyr 1). The kinase activity was measured in the absence of insulin and at $0.1-1000 \mathrm{nmol} / \mathrm{l}$ insulin using equal amounts of partially purified insulin receptor as determined by insulin binding. The curves represent the mean value of three experiments 
Table 2. Protein recovery distribution of marker enzyme specific activities and activity ratios in subcellular membrane fractions from skeletal muscle

\begin{tabular}{|c|c|c|c|}
\hline Membrane fractions & $\begin{array}{l}\text { Plasma } \\
\text { membranes }\end{array}$ & $\begin{array}{l}\text { Low density } \\
\text { membranes }\end{array}$ & Homogenate \\
\hline $\begin{array}{l}\text { Ouabain sensitive } \\
\mathrm{Na} / \mathrm{K}-\mathrm{ATP} \text { ase } \\
\left(\mathrm{nmol} \mathrm{Pi} \cdot-\mathrm{min}^{-1} \cdot \mathrm{mg}\right. \\
\text { of protein } \\
\text {-1) }\end{array}$ & $44.3 \pm 5.72$ & $14.5 \pm 2.54$ & $2.8 \pm 0.44$ \\
\hline Activity ratio (\%) & 100 & 32.3 & 6.3 \\
\hline $\begin{array}{l}\text { UDP-galactosyl- } \\
\text { transferase } \\
\left(\text { nmol } \cdot-\mathrm{min}^{-1} \cdot \mathrm{mg}\right. \\
\left.\text { of protein }{ }^{-1}\right)\end{array}$ & $2.27 \pm 0.19$ & $5.5 \pm 0.73$ & $1.3 \pm 0.1$ \\
\hline Activity ratio (\%) & 41.3 & 100 & 23.6 \\
\hline
\end{tabular}

Results are expressed as the mean \pm SEM of each experiment. Activity ratios are calculated by setting the specific activity of the most enriched membrane fraction at $100 \%$ and those in other membrane fractions relative to that specific value

mined as marker enzymes (Table 2). Compared to the crude homogenate $\mathrm{Na} / \mathrm{K}$-ATPase was enriched approximately $15-18$ fold in the plasma membrane fraction. The cross contamination of both fractions is in a similar range to that found in adipocytes [38]. Both fractions were used for PAGE and Western blotting. Figure 7 shows an autoradiogram of an immunoblot with antibody directed against GLUT 4. In membranes from both rats clearly the insulin induced decrease of LDM-labelling and a concomitant increase of plasma membrane labelling is visible. The analogous experiments were performed with antibody directed against GLUT 1 . Figure 8 shows an autoradiogram of GLUT 1 labelling. The largest amount of label is found in the LDM fraction. In contrast to the data obtained with GLUT 4 no effect of insulin treatment is visible. The insulin stimulation experiment was repeated once with the same result, i.e. no difference in the effect of insulin between SHR and Wistar-Kyoto rats was detectable. Unstimulated GLUT 4 levels were determined in four experiments. Scanning densitometry revealed no differences between the groups.

\section{Discussion}

The data show that no abnormality of the effect of insulin on the insulin receptor kinase from skeletal muscle of SHR is detectable. This discriminates this insulin-resistant animal model from other insulin-resistant animal models such as the Zucker rat [10], the gold-thio-glucose-mouse [13], ob/ob mice [14] and streptozotocin-treated rats [15] as well as human Type 2 diabetes $[10,18,19]$. This suggests that insulin resistance in hypertension is possibly caused by different molecular mechanisms than the insulin resistance in other pathophysiological states. On the other hand the interpretation of our data is limited to this specific animal model of hypertension. It is possible that SHR might not be a representative model for other states of hypertension. Furthermore when SHR are compared to other models of insulin resistance clear differences concerning the degree of insulin resistance are found. The moderate increase of insulin levels suggests that the insulin resistance in SHR is mild compared to obese Zucker rats which show a clearly more pronounced hyperinsulinaemia $[12,13]$.

Several mechanisms have been proposed for the effect of insulin on glucose transport in skeletal muscle. While some authors favour a combined model involving carrier translocation and carrier activation as that seen in adipocytes [16] others suggest that only carrier activation is important [39]. In our study we determined two factors, carrier number and carrier translocation. We could not detect differences in carrier numbers. The data concerning GLUT 4 translocation in skeletal muscle clearly confirm the earlier demonstrated insulin-induced translocation from intracellular membranes to the plasma membrane [16]. Similarly, as described by others, an approximately two-fold increase of GLUT 4 labelling is found [17]. There is no evidence for a defect of GLUT 4 translocation in the SHR. An abnormality of intrinsic carrier activity as a possible reason for the insulin resistance clearly cannot be excluded with the present study.

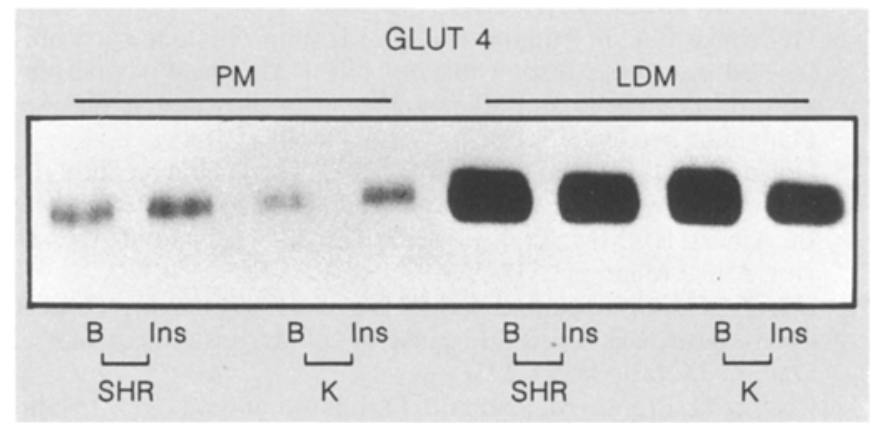

Fig. 7. Western blot analysis of GLUT 4 in subcellular membrane fractions of rat hindlimb muscles under basal conditions and after stimulation with insulin in vivo. Total protein $15 \mu \mathrm{g}$ from plasma membranes (PM) and low density membranes (LDM) was immunoblotted using anti-GLUT 4 antiserum. Immunolabelled bands were visualized by horseradish peroxidase-labelled anti-rabbit Ig followed by chemiluminescence as described in the Materials and methods section. B, basal; Ins, insulin stimulation in vivo as described. The insulin stimulation experiment was repeated once with the same result

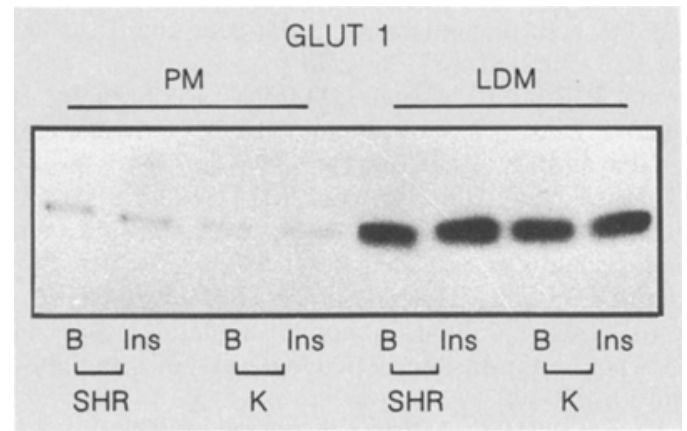

Fig. 8. Western blot analysis of GLUT 1 in subcellular membrane fractions of rat hindlimb muscles under basal conditions and after stimulation with insulin in vivo. Total protein $15 \mu \mathrm{g}$ from plasma membranes (PM) and low density membranes (LDM) was immunoblotted using anti-GLUT 1 antiserum. Immunolabelled bands were visualized by horseradish peroxidase-labelled anti-rabbit Ig followed by chemiluminescence as described in the Materials and methods section. B, basal; Ins, insulin stimulation in vivo as described. The insulin stimulation experiment was repeated once with the same result 
Acknowledgements. This study was supported by a grant of the Deutsche Forschungsgesellschaft.

\section{References}

1. Ferrannini E, Buzzigoli G, Bonadonna R et al. (1987) Insulin resistance in essential hypertension. N Engl J Med 317:350-357

2. Shen DC, Shien SM, Fuh MT, Wu DA, Chen YDI, Reaven GM (1988) Resistance to insulin-stimulated-glucose uptake in patients with hypertension. J Clin Endocrinol Metab 66: 580-583

3. Swislocki ALM, Hoffmann BB, Reaven GM (1989) Insulin resistance, glucose intolerance and hyperinsulinemia in patients with hypertension. Am J Hypertens 2: 419-423

4. Reaven GM (1988) Role of insulin resistance in human disease. Diabetes 37: 1595-1607

5. Modan M, Halkin H, Almog S et al. (1985) Hyperinsulinemia: a link between hypertension, obesity and glucose intolerance. $J$ Clin Invest 75: 809-817

6. Manicardi V, Camellini L, Bellodi G, Coscelli C, Ferrannini E (1986) Evidence for an association of high blood pressure and hyperinsulinemia in obese man. J Clin Endocrinol Metab 62: 1302-1304

7. Fournier AM, Gadia MT, Kubrusly DB, Skyler JS, Sosenko JM (1986) Blood pressure, insulin, and glycemia in non diabetic subjects. Am J Med 80: 861-864

8. DeFronzo RA, Ferrannini E (1991) Insulin resistance: a multifaceted syndrome responsible for NIDDM, obesity, hypertension, dyslipidemia, and atherosclerotic cardiovascular disease. Diabetes Care 14: 173-194

9. Häring HU, Obermaier-Kusser B (1990) The insulin receptor: its role in insulin action and in the pathogenesis of insulin resistance. In: Alberti KGMM, Krall LP (eds) The diabetes annual/5, Elsevier, Amsterdam, pp. 537-568

10. Häring HU, Obermaier B, Ermel B et al. (1987) Insulin receptor kinase defects as a possible cause of cellular insulin resistance. Diabete Metab 13: 284-293

11. Crettaz M, Prentki M, Zaninetti D, Jeanrenaud B (1980) Insulin resistance in soleus muscle from obese Zucker rats. Biochem J 186: $525-534$

12. Crettaz M, Zaninetti D, Jeanrenaud B (1981) Insulin resistance in heart and skeletal muscles of genetically obese Zucker rats. Biochem Soc Trans 9: 524-525

13. Le Marchand Y, Gremeauy T, Ballotti R, Van Obenghen E(1985) Insulin receptor tyrosine kinase is defective in skeletal muscle of insulin-resistant obese mice. Nature (London) 315:676-679

14. Gremeaux T, Tanti JF, Van Oberghen E, Le Marchand-Brustel YLE (1987) Alteration of insulin receptor kinase in obese insulin resistant mice. Biochemie 69:387-393

15. Burant CF, Treutelaar TIK, Buse MG (1986) Diabetes induced functional and structural changes in insulin receptors from rat skeletal muscle. J Clin Invest 77: 260-270

16. Klip A, Ramlal T, Bilan PJ, Cartee GD (1990) Recruitment of GLUT 4 glucose transporters by insulin in diabetic rat skeletal muscle. Biochem Biophys Res Commun 172: 728-736

17. Garvey WT, Huecksteadt TP, Birnbaum MJ (1989) Pretranslational suppression of an insulin-responsive glucose transporter in rats with diabetes mellitus. Science 245: 60-63

18. Arner P, Pollare T, Lithell H, Livingston JN (1987) Defective insulin receptor tyrosine kinase in human skeletal muscle in obesity and type 2 (non-insulin-dependent) diabetes mellitus. Diabetologia 30: 437-440

19. Obermaier-Kusser B, White MF, Pongratz D et al. (1989) A defective intramolecular autoactivation cascade may cause the reduced kinase activity of the skeletal muscle insulin receptors from patients with non-insulin-dependent diabetes mellitus. J Biol Chem 264: $9497-9564$

20. Freidenberg GR, Henry RR, Klein HH, Olefsky JM (1987) Decreased kinase activity of insulin receptors from adipocytes of non-insulin-dependent diabetic subjects. J Clin Invest 79:240-250

21. Caro JF, Ittoop O, Pories WJ et al. (1986) Studies on the mechanism of insulin resistance in the liver from humans with non-insulin-dependent diabetes. J Clin Invest 78: 249-258
22. Garvey WT, Huecksteadt TP, Matthei S, Olefsky JM (1988) Role of glucose transporters in the cellular insulin resistance of the type II non-insulin-dependent diabetes mellitus. J Clin Invest 81 : $1528-1536$

23. Pedersen O, Bak JF, Andersen PH, Lund S et al. (1990) Evidence against altered expression of GLUT 1 or GLUT 4 in skeletal muscle of patients with obesity or type 2 (non-insulin-dependent) diabetics. Diabetes 39: 865-870

24. Handberg A, Vaag A, Damsbo P, Beck-Nielsen H, Vinten J (1990) Expression of insulin regulatable glucose transporters in skeletal muscle from type 2 (non-insulin-dependent) diabetic patients. Diabetologia 33: 625-627

25. Vogt B, Carrascosa JM, Mushak J, Seffer E, Häring HU (1992) Altered distribution of GLUT 4 and GLUT 1 in plasma membranes of skeletal muscle from type 2 (non-insulin-dependent patients. Diabetologia (in press)

26. Mondon CE, Reaven GM (1988) Evidence of abnormalities of insulin metabolism in rats with spontaneous hypertension. Metabolism 37: 303-305

27. Reaven GM, Chang H, Hoffmann BB, Azhar S (1989) Resistance to insulin-stimulated glucose uptake in adipocytes isolated from spontaneous hypertensive rats. Diabetes 38: 1155-1160

28. Eriksson J, Franssila-Kallunki A, Ekstrand A et al. (1989) Early metabolic defects in persons at increased risk for non-insulin-dependent diabetes mellitus. NEngl J Med 321: 337-343

29. Warram JH, Martin BH, Krolwski AS, Soeldner JS, Kahn CR (1990) Slow glucose removal rate and hyperinsulinemia precede the development of type 2 diabetes in the offspring of diabetic patients. Ann Intern Med 113: 909-915

30. DeFronzo RA (1988) The triumvirate: $\beta$-cell, muscle. liver. A collusion responsible for NIDDM. Diabetes 37: 667-687

31. Obermaier B, Ermel B, Biemer E, Kirsch D, Machicao F, Häring HU (1985) Insulin receptor kinase in human skeletal muscle. FEBS Lett 186: 85-88

32. McPherson EA (1985) Analysis of radioligand binding experiments. A collection of computer programms for the IBM PC. J Pharmacol Methods 14: 213-228

33. Pilch PF, Czech MP (1980) The subunit structure of the high affinity insulin receptor: evidence for a disulfide linked receptor complex in fat cell and liver plasma membrane. J Biol Chem 255: $1722-1731$

34. Laemmli UK (1970) Cleavage of structural protein during the assembly of the head of bacteriophage $T_{4}$. Nature (London) 227: 680-685

35. Braun S, Raymond WE, Racker E (1984) Synthetic tyrosine polymers as substrates and inhibitors of tyrosine-specific protein kinases. J Biol Chem 259: 2051-2054

36. Schimmel SD, Kent C, Bischoff R, Vagelos R (1973) Plasma membranes from cultured muscle cells: isolation procedure and separation of putative plasma-membrane marker enzymes. Proc Nat Acad Sci USA 70: 3195-3199

37. Verdon B, Berger E (1983) Enzymatic analysis. In: Bergmeyer HU (ed) vol 3. Verlag Chemie, Weinheim, pp 374-381

38. Mühlbacher C, Karnieli E, Schaff P et al. (1988) Phorbol esters imitate in rat fat cells the full effect of insulin on glucose carrier translocation but not on 3-O-methylglucose transport activity. Biochem J 249: 865-870

39. Plough T, Galbo H, Vinten J (1987) Stimulation of glucose transport in skeletal muscle by insulin and contractions is caused by redistribution of glucose transporters in the plasma membrane. Diabetologia 29: 570A-571A (Abstract)

Received: 27 December 1991

and in revised form: 6 April 1992

Dr. H.U.Häring

Institut für Diabetesforschung

Kölner Platz 1

W-8000 München 40

FRG 